\title{
Article \\ Epidemiology, Distribution and Identification of Ticks on Livestock in Pakistan
}

\author{
Sadia Salim Khan ${ }^{1}$, Haroon Ahmed ${ }^{1}$ (D), Muhammad Sohail Afzal ${ }^{2}$, Mobushir Riaz Khan ${ }^{3}$ D, Richard J. Birtles ${ }^{4}$ \\ and Jonathan D. Oliver $5, * \mathbb{D}$
}

1 Department of Biosciences, COMSATS University Islamabad (CUI), Park Road, Chakh Shahzad, Islamabad 45550, Pakistan; sadiasalim121@gmail.com (S.S.K.); haroonahmad12@yahoo.com (H.A.)

2 Department of Life Sciences, School of Science, University of Management \& Technology (UMT), Lahore 54770, Pakistan; sohail.ncvi@gmail.com

3 School of Environmental Science, Charles Sturt University, Albury, NSW 2640, Australia; mobkhan@csu.edu.au

4 School of Science, Engineering and Environment, University of Salford, Salford M5 4NT, UK; r.j.birtles@salford.ac.uk

5 Environmental Health Sciences, School of Public Health, University of Minnesota, Minneapolis, MN 55455, USA

* Correspondence: joliver@umn.edu

check for updates

Citation: Khan, S.S.; Ahmed, H.; Afzal, M.S.; Khan, M.R.; Birtles, R.J.; Oliver, J.D. Epidemiology, Distribution and Identification of Ticks on Livestock in Pakistan. Int. J. Environ. Res. Public Health 2022, 19, 3024. https://doi.org/10.3390/ ijerph19053024

Academic Editor: Paul B. Tchounwou

Received: 12 January 2022 Accepted: 1 March 2022

Published: 4 March 2022

Publisher's Note: MDPI stays neutral with regard to jurisdictional claims in published maps and institutional affiliations.

Copyright: () 2022 by the authors. Licensee MDPI, Basel, Switzerland. This article is an open access article distributed under the terms and conditions of the Creative Commons Attribution (CC BY) license (https:// creativecommons.org/licenses/by/ $4.0 /)$.

\begin{abstract}
Background: Ticks are ectoparasites that transmit a variety of pathogens that cause many diseases in livestock which can result in skin damage, weight loss, anemia, reduced production of meat and milk, and mortality. Aim: The aim of this study was to identify tick species and the distribution on livestock hosts (sheep, goat, dairy cattle, and buffalo) of Punjab, Khyber Pakhtunkhwa Province and Islamabad from October 2019 to November 2020. Materials and Methods: Surveillance was performed to calculate the prevalence of ticks on livestock. Tick prevalence data (area, host, breed, gender, age, and seasonal infestation rate) was recorded and analyzed. Results: A total of 2080 animals were examined from selected farms, and, of these, 1129 animals were tick-infested. A total of 1010 male tick samples were identified to species using published keys. Haemaphysalis punctata, Haemaphysalis sulcata, Hyalomma anatolicum, Hyalomma detritum, Hyalomma dromedarii, Hyalomma excavatum, Hyalomma marginatum, Hyalomma rufipes, Rhipicephalus decoloratus Rhipicephalus microplus, and Rhipicephalus sanguineus were collected from goats, sheep, buffalo, and cattle. The overall rates of tick infestation on livestock were 34.83\% (buffalo), 57.11\% (cattle), 51.97\% (sheep) and 46.94\% (goats). Within each species, different breeds demonstrated different proportions of infestation. For cattle breeds, infestation proportions were as follows: Dhanni $(98.73 \%)$, Jersey $(70.84 \%)$ and the Australian breed of cattle ( $81.81 \%)$. The Neeli Ravi breed ( $40 \%)$ of buffalo and the Beetal breed $(57.35 \%)$ of goats were the most highly infested for these species. Seasonally, the highest prevalence of infestation (76.78\%) was observed in summer followed by $70.76 \%$ in spring, $45.29 \%$ in autumn, and $20 \%$ in winter. The prevalence of tick infestation in animals also varied by animal age. In goats, animals aged 4-6 years showed the highest prevalence (90\%), but in cattle, the prevalence of ticks was highest $(68.75 \%)$ in 6 months-1-year-old animals. 1-3 years old buffalo (41.07\%) and 6 months-1 year sheep $(65.78 \%)$ had the highest prevalence rate. Females had significantly higher infestation rates $(61.12 \%, 55.56 \%$ and $49.26 \%$, respectively) in cattle, sheep, and goats. In buffalo, males showed a higher prevalence $(38.46 \%)$ rate. Conclusions: This study showed tick diversity, infestation rate, and numerous factors (season, age, and gender of host) influencing tick infestation rate in different breeds of cattle, sheep, goats, and buffalo in Punjab Province, Khyber Pakhtunkhwa Province, and Islamabad, Pakistan. Higher tick burdens and rates of tick-borne disease reduce production and productivity in animals. Understanding tick species' prevalence and distribution will help to develop informed control measures.
\end{abstract}

Keywords: livestock; ticks; tick-borne diseases 


\section{Introduction}

Pakistan is a highly agricultural country with much of its population involved in animal husbandry. Forty-three percent of workers, especially in rural areas, work in the agricultural sector [1]. Parasites, such as ticks, impact animal health and production [2-4]. An amount of 49.6 million cattle, 41.2 million buffalo, 78.2 million goats, and 30.9 million sheep reside in Pakistan [5]. Cattle and goats are raised all over the country in grazing areas, while most sheep are found in hilly areas and buffalo are mostly raised in Punjab and Sindh [6-8].

Ticks are ectoparasites that can transmit a variety of pathogens that cause many diseases in cattle. These may result in skin damage, weight loss, abortion, and mortality, leading to substantial economic losses [9-11]. In Pakistan, cattle, and buffalo are mostly infested with Rhipicephalus and Hyalomma ticks [7,12-17] which transmit pathogens, such as Anaplasma marginale, Babesia bigemina, Babesia bovis and Theileria annulate [18-24]. Ovine and caprine theileriosis are caused by Theileria ovis and Theileria lestoquardi in sheep and goats, and these pathogens are transmitted by Haemaphysalis and Hyalomma ticks [25-29]. Ticks may also transmit pathogens to humans, especially those working closely with animals. Crimean-Congo hemorrhagic fever virus, transmitted by ticks in the genus Hyalomma, is of particular concern [30-32].

Despite the many negative impacts on the health of livestock and the variety of tickborne pathogens, tick infestation of livestock has been little documented in some areas of Punjab, Swat, and in Islamabad. Previous studies have examined the prevalence of tick infestation on livestock in some areas of Pakistan and they are reported in different hosts in Pakistan, e.g., sheep and goats $[4,7,33]$ and bovines $[7,14,20,21,34]$. Some studies of tick prevalence in Pakistan are focused on specific regions with small sample sizes of ticks. Ticks and tick-borne diseases are neglected issues and there are few tick control products available in markets [35].

The Punjab Province of Pakistan is highly rural, and many people rely on livestock rearing for their livelihood. During the summer feasting holiday of Eid ul Azha, many herdsmen bring animals to Punjab from other provinces, and this event corresponds to an annual increase in cases of Crimean-Congo hemorrhagic fever [4,36]. It is likely that ticks carrying livestock pathogens are transferred between animal herds maintained in close quarters at this time. There is a need for appropriate strategies for the management of ticks and tick-borne diseases, and this requires current data on the prevalence and distribution of ticks on a variety of hosts. The objective of this work was to better understand the dynamics of tick-borne disease transmission among both livestock and humans in Punjab Province, Khyber Pakhtunkhwa Province (KPK), and Islamabad. To do so, we performed large-scale surveillance of tick infestation on livestock, including cattle, buffalo, sheep, and goats. This study will help to produce coherent tick control and education programs tailored to the regions.

\section{Materials and Methods}

\subsection{Study Area}

This study focused on Punjab Province, Khyber Pakhtunkhwa Province and Islamabad from October 2019 to November 2020. The study sites are shown in Figure 1. Punjab Province is the most populated province of Pakistan, and this area contains 7 million sheep, 22 million buffalo, 24 million goats, and 18.8 million cattle [7,37]. The climate of Punjab is dry, as rainfall is less than $200 \mathrm{~mm}$ annually. The annual mean temperature of this area varies between its cold zone $\left(7-12{ }^{\circ} \mathrm{C}\right)$, and its warm zone (above $25^{\circ} \mathrm{C}$ ) [38]. During the summer, high humidity, and temperatures provide favorable conditions for tick growth and infestation. The Swat valley is located within KPK in northern Pakistan. In its Malakand division, there are more than 80,000 sheep, 236,000 goats, 253,000 cattle, and 117,000 buffalo. The average temperature of Swat varies between $10^{\circ} \mathrm{C}$ and $15^{\circ} \mathrm{C}[39,40]$. Islamabad is the capital of Pakistan. To its northeast, in Rawalpindi (Punjab), there are many livestock farms and rural areas where people rear livestock. Islamabad is the largest city in Pakistan 
and has a humid climate with temperatures ranging from $-3.9^{\circ} \mathrm{C}$ to $46 .{ }^{\circ} \mathrm{C}$ (January to June) [41].

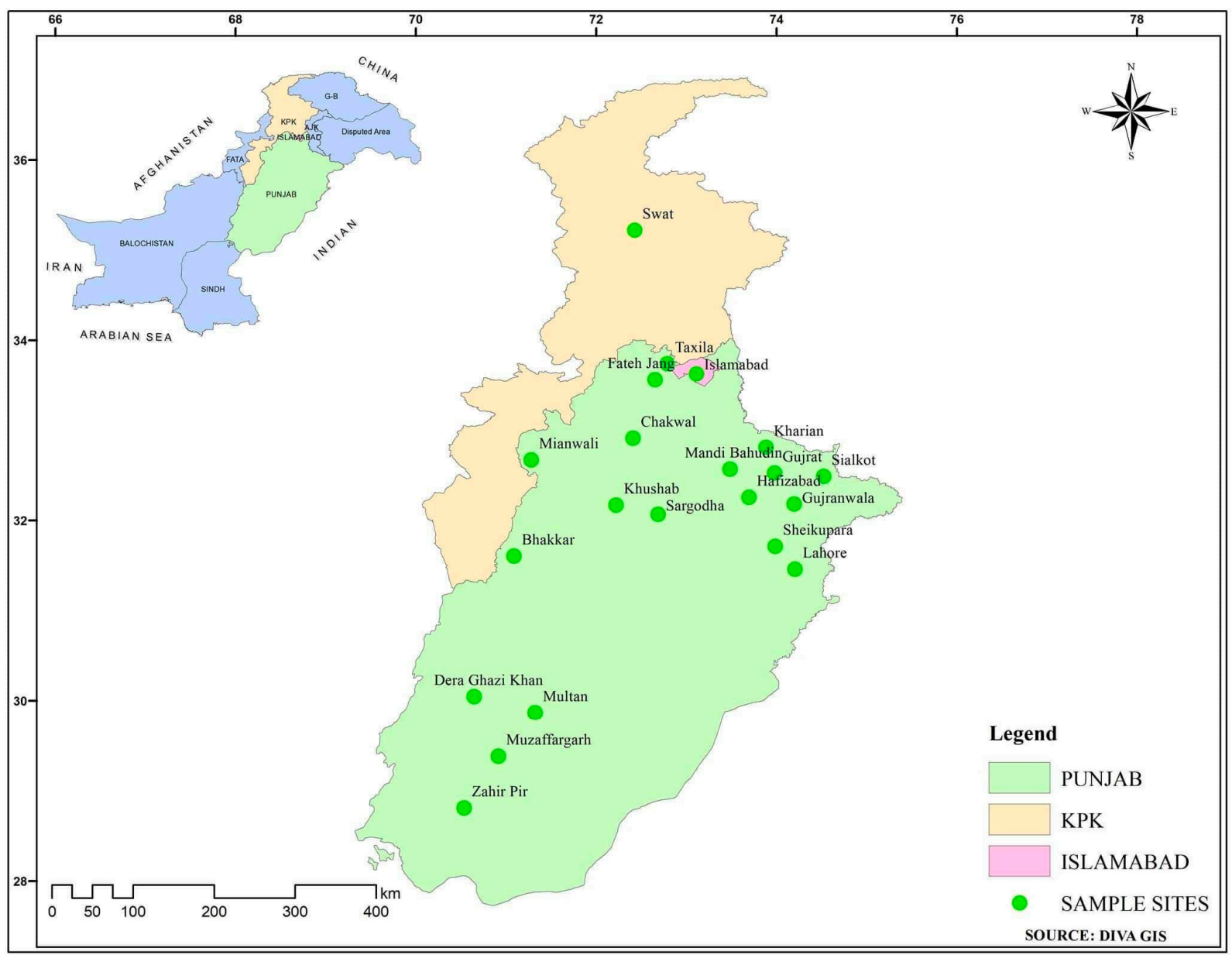

Figure 1. Map of Pakistan showing sampling location for this study.

\subsection{Sample Size, Collection, and Preservation}

Seventy-three livestock farms were selected for tick sampling based on the availability of permission to sample. Four villages were selected from each district shown in Figure 1. Six livestock farms were visited in each village. Farms were at least ten $\mathrm{km}$ away from the next farm in urban areas and more than five $\mathrm{km}$ away in rural areas. Livestock varying in age, breed, and sex housed in barns were selected on the supposition that if ticks are present on the farm, then at least $50 \%$ of the livestock would be infested on that farm [42]. They were checked for ticks using a standardized protocol [43]. Any ticks encountered were carefully removed with forceps to ensure they remained intact, including mouthparts [44]. Collection data regarding location, date, host species, breed, age, and sex were recorded with the help of veterinarians. Ticks were preserved in $70 \%$ ethanol.

\subsection{Identification of Male Ticks}

Morphological characters of ticks were observed using a Leica EZ4W stereomicroscope (Leica EZ4W) and identified using taxonomic keys [45-48].

\subsection{Statistical Analysis}

Prevalence data (area of collection, host, breed, gender, age, and seasonal infestation rate of ticks) were analyzed by using Jomovi 1.6.23 software and statistical analysis was done in $\mathrm{R}$ language (version 4.0.5). The chi-square test, was calculated to assess the 
difference between two distributions (i.e., non-infested and tick-infested animals) and $p<0.05$ was considered a significant level between groups [49].

\section{Results}

\subsection{Tick Prevalence on Livestock}

A total of 2080 animals, varying in age, breed, and sex, were selected and examined for ticks. Of these, 1141 animals (31 buffalo, 791 cattle, 66 sheep, and 253 goats) were found to be tick infested. The proportion of male tick infestation was 34.83\% for buffalo, 59.69\% for cattle, $46.93 \%$ for goats, and $51.96 \%$ for sheep, as shown in Table 1 . The unidentified female (1324) and immature ticks (531) on the four host animals (goat, sheep, buffalo, and cattle) were omitted from analysis and discussion due to the difficulty in identification. There was a statistically significant difference $\left(p=0.001, \chi^{2}=41\right)$ between the rates of non-infested and tick-infested animals (Table 1).

Table 1. Host wise prevalence rate of male ticks.

\begin{tabular}{ccccc}
\hline Hosts & Non-Infested & Tick-Infested & Total & Prevalence (\%) \\
\hline Buffalo & 58 & 31 & 89 & 34.83 \\
Cattle & 534 & 791 & 1325 & 59.69 \\
Goat & 286 & 253 & 539 & 46.93 \\
Sheep & 61 & 66 & 127 & 51.96 \\
\hline Chi-square test $(p$-value $)$ & \multicolumn{2}{c}{$41\left(0.001{ }^{*}\right)$} \\
* Significant difference $(p<0.05)$.
\end{tabular}

There were high proportions of tick infestation in both indigenous and exotic breeds of cattle. Dhanni $(98.73 \%)$, Jersey $(70.84 \%)$, and the Australian breed of cattle $(81.81 \%)$ were heavily tick-infested, while the Sahiwal breed was less infested (54.34\%). In buffalo, the tick infestation rate was higher (40\%) in the Neeli Ravi breed as compared to the Ravi breed. In goats, the Beetal breed was highly infested (57.35\%) and Lal Puri (39.87) was least infested. There were statistically significant differences $(p<0.05)$ in tick infestation rates among some breeds of cattle $\left(\chi^{2}=65.8\right)$, buffalo $\left(\chi^{2}=3.86\right)$, and goats $\left(\chi^{2}=18.5\right.$; Table 2$)$.

Table 2. Breed wise prevalence rate of male ticks.

\begin{tabular}{|c|c|c|c|c|c|}
\hline Hosts & Breeds & Non-Infested & Tick-Infested & Total & Prevalence $(\%)$ \\
\hline \multirow{6}{*}{ Cattle } & Australian & 12 & 54 & 66 & 81.81 \\
\hline & Cross breed & 39 & 97 & 136 & 71.32 \\
\hline & Dhanni & 1 & 78 & 79 & 98.73 \\
\hline & Freisian & 181 & 217 & 398 & 54.52 \\
\hline & Sahiwal & 284 & 338 & 622 & 54.34 \\
\hline & Jersey & 7 & 17 & 24 & 70.84 \\
\hline Chi-square test ( $p$-value) & & $65.8(0.001 *)$ & & & \\
\hline \multirow{2}{*}{ Buffalo } & Neeli Ravi & 42 & 28 & 70 & 40 \\
\hline & Ravi & 16 & 3 & 19 & 15.78 \\
\hline Chi-square test ( $p$-value) & & $3.86(0.049 *)$ & & & \\
\hline Sheep & Pure Kajla & 61 & 66 & 127 & 51.96 \\
\hline \multirow{4}{*}{ Goats } & Rajanpuri & 34 & 26 & 60 & 43.34 \\
\hline & Beetal & 58 & 78 & 136 & 57.35 \\
\hline & Desi Teddy & 109 & 76 & 185 & 41.08 \\
\hline & Lal puri & 95 & 63 & 158 & 39.87 \\
\hline Chi-square test ( $p$-value) & & $18.5\left(0.001^{*}\right)$ & & & \\
\hline
\end{tabular}

* Significant difference $(p<0.05)$. 
The age of the animals affected the prevalence of tick infestation. In goats, animals aged 4-6 years showed the highest prevalence (90\%) followed by 1-3 years (54.67\%), 6 months-1 year (41.86\%), and up to 6 months (40.83\%) age groups. In cattle, the rate of tick infestation was highest (62.29\%) in 4-6 years old animals, followed by $1-3$ years old (60.93\%), 7-14 years old (50\%), 6 months-1 year (46.31\%), and up to 6 months old animals (40\%). In buffalo, $1-3$ years (41.07\%), and in sheep, 6 months -1 year $(65.78 \%)$ old animals had the highest rates of tick infestation.

In cattle, sheep, and goats, females had a higher prevalence of tick infestation $(61.12 \%$, $55.56 \%$ and $48.25 \%$, respectively) than males (59.06\%, $49.31 \%$ and $45.56 \%$, respectively). In buffalo, males showed a higher prevalence (38.46\%) of tick infestation than females $(32.65 \%)$ (Table 3).

Table 3. Prevalence of male tick infestation in relation to age and gender.

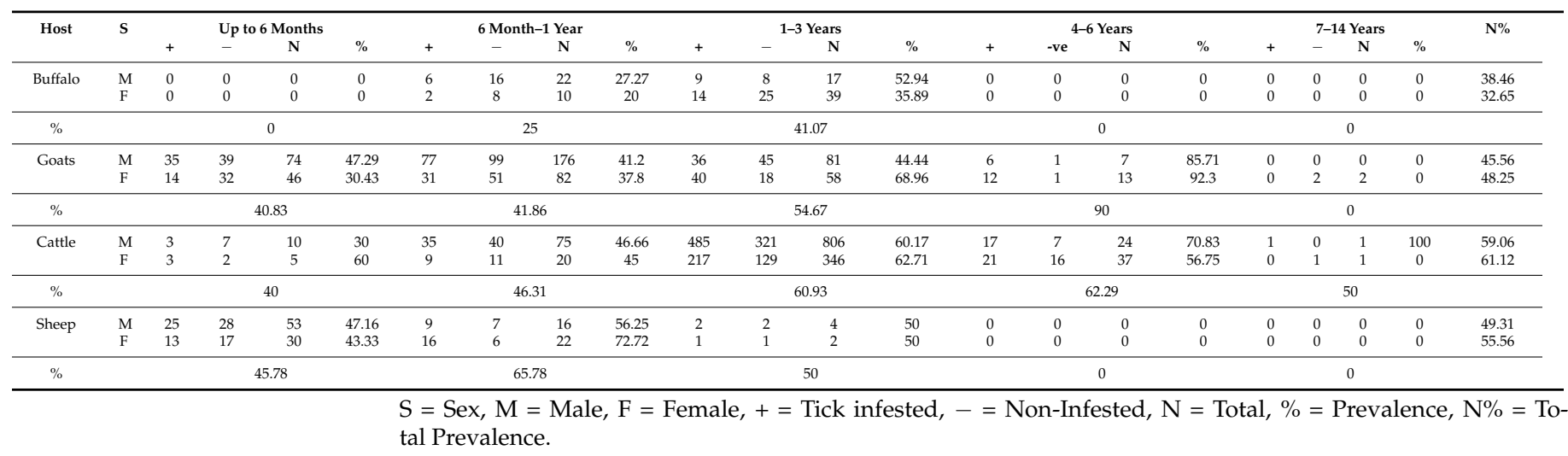

\subsection{Geographic and Seasonal Tick Prevalence}

There were differences in tick burdens in different areas with higher infestation levels in Hafizabad (100\%) and Mandi Bahudin (89.55\%), and lower infestation levels in Sheikhupura (20\%; Table 4).

Table 4. Area wise prevalence rate of male ticks.

\begin{tabular}{|c|c|c|c|c|c|c|}
\hline Area & Latitude $\mathbf{N}$ & Longitude E & Non-Infested & Tick Infested & Total & Prevalence (\%) \\
\hline Bhakkar & 31.6082 & 71.0854 & 8 & 14 & 22 & 63.63 \\
\hline Chakwal & 32.9172 & 72.4081 & 14 & 106 & 120 & 88.34 \\
\hline Dera Ghazi Khan & 30.0489 & 70.6455 & 26 & 16 & 42 & 38.09 \\
\hline Fateh Jang & 33.5673 & 72.6506 & 32 & 35 & 67 & 52.23 \\
\hline Gujranwala & 32.1877 & 74.1945 & 4 & 15 & 19 & 78.94 \\
\hline Gujrat & 32.5295 & 73.9771 & 36 & 26 & 62 & 41.93 \\
\hline Hafizabad & 32.2623 & 73.6945 & 0 & 30 & 30 & 100 \\
\hline Islamabad & 33.6296 & 73.1123 & 73 & 124 & 197 & 62.94 \\
\hline Kharian & 32.8143 & 73.8831 & 94 & 116 & 210 & 55.23 \\
\hline Khushab & 32.1748 & 72.219 & 54 & 61 & 115 & 53.04 \\
\hline Kunjah & 32.5295 & 73.9771 & 10 & 21 & 31 & 67.74 \\
\hline Lahore & 31.4635 & 74.2047 & 155 & 168 & 323 & 52.01 \\
\hline Mandi Bahudin & 32.5742 & 73.4828 & 7 & 60 & 67 & 89.55 \\
\hline Mianwali & 32.6749 & 71.2785 & 61 & 41 & 102 & 40.19 \\
\hline Multan & 29.8717 & 71.3231 & 47 & 41 & 88 & 46.59 \\
\hline Makwal & 30.5851 & 70.7258 & 82 & 81 & 163 & 49.69 \\
\hline Muzaffargarh & 29.3817 & 70.9131 & 15 & 5 & 20 & 25 \\
\hline Sargodha & 32.074 & 72.6861 & 2 & 13 & 15 & 86.67 \\
\hline Sheikupara & 31.7167 & 73.985 & 24 & 6 & 30 & 20 \\
\hline Sialkot & 32.4945 & 74.5229 & 12 & 23 & 35 & 65.71 \\
\hline Swat & 35.2227 & 72.4258 & 56 & 38 & 94 & 40.42 \\
\hline Talagang & 32.9172 & 72.4081 & 15 & 7 & 22 & 31.81 \\
\hline Taunsa & 30.7046 & 70.6574 & 11 & 12 & 23 & 52.17 \\
\hline Taxila & 33.7408 & 72.7858 & 58 & 50 & 108 & 46.29 \\
\hline Zahir Pir & 28.8107 & 70.5324 & 43 & 32 & 75 & 42.67 \\
\hline
\end{tabular}


Table 5 shows the overall seasonal tick prevalence in Punjab Province and Islamabad. The highest prevalence $(76.78 \%$ ) was observed in summer followed by $70.76 \%$ in spring, $45.29 \%$ in autumn, and $20 \%$ in winter. With respect to seasons, significant differences $(p<0.05)$ were observed in the proportions of non-infested and tick-infested animals.

Table 5. Seasonal prevalence rate of male ticks.

\begin{tabular}{ccccccc}
\hline Season & Non-Infested & Tick Infested & Total & Prevalence (\%) & Chi-Square $\left(\chi^{2}\right)$ & $p$-Value \\
\hline Autumn & 756 & 626 & 1382 & 45.29 & & \\
Summer & 140 & 463 & 603 & 76.78 & 189 & $0.001 *$ \\
Winter & 24 & 6 & 30 & 20 & 70.76 & \\
Spring & 19 & 46 & 65 & & \\
\hline
\end{tabular}

* Significant $(p<0.05)$.

\subsection{Tick Species Identification}

Tick samples (males and females of different life stages) were collected from 1141 animals (sheep, goats, cattle, and buffalo) from different areas of Punjab Province, KPK, and Islamabad. An amount of 1012 male ticks were found and identified to species. Because the ticks were collected from livestock, most immatures and females were engorged, obscuring diagnostic characters. This was particularly of concern for Hyalomma ticks for which diagnostic characters often include the shape of the genital aperture [47]. Eleven species of ticks (H. punctata, H. sulcata, H. anatolicum, H. detritum, $H$. dromedarii, $H$. excavatum, H. marginatum, H. rufipes, R. decoloratus, $R$. microplus, and $R$. sanguineus) were identified. Only goats and cattle were infested with $H$. dromedarii, and H. sulcata was only identified on buffalo and sheep (Table 6). Table 7 shows the tick species (male) found on various animals.

Table 6. Number of male ticks by species found in Punjab, Islamabad, and KPK, Pakistan.

\begin{tabular}{|c|c|c|c|c|c|c|c|c|c|c|c|c|}
\hline \multirow[b]{2}{*}{ Province } & \multirow[b]{2}{*}{ Areas } & \multicolumn{11}{|c|}{ Tick Species } \\
\hline & & 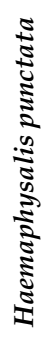 & 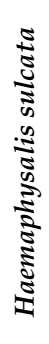 & 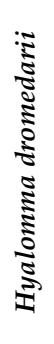 & 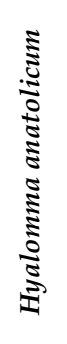 & 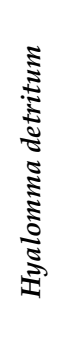 & 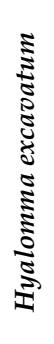 & 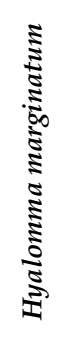 & 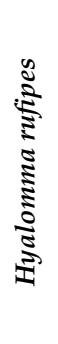 & 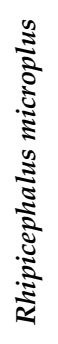 & 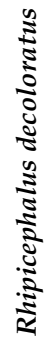 & 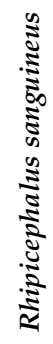 \\
\hline \multirow{17}{*}{ Punjab } & Mandi Bahudin & 1 & 0 & 0 & 41 & 0 & 0 & 3 & 0 & 3 & 2 & 6 \\
\hline & Kharian & 1 & 0 & 1 & 12 & 3 & 0 & 4 & 0 & 4 & 3 & 2 \\
\hline & Dera Ghazi Khan & 3 & 1 & 1 & 8 & 24 & 10 & 12 & 0 & 1 & 2 & 45 \\
\hline & Muzaffargarh & 0 & 0 & 0 & 4 & 0 & 0 & 1 & 0 & 1 & 1 & 10 \\
\hline & Mianwali & 0 & 0 & 1 & 6 & 4 & 4 & 03 & 0 & 0 & 0 & 3 \\
\hline & Zahir Pir & 0 & 0 & 2 & & 5 & 3 & 1 & 0 & 0 & 0 & 12 \\
\hline & Fateh Jang & 0 & 0 & 0 & 10 & 0 & 1 & 2 & 0 & 4 & 1 & 4 \\
\hline & Sheikupara & 0 & 0 & 0 & 1 & 0 & 0 & 1 & 0 & 8 & 0 & 0 \\
\hline & Lahore & 0 & 0 & 0 & 45 & 35 & 6 & 10 & 0 & 0 & 3 & 0 \\
\hline & Chakwal & 0 & 0 & 0 & 71 & 25 & 1 & 41 & 1 & 10 & 2 & 0 \\
\hline & Sargodha & 0 & 0 & 0 & 10 & 0 & 0 & 0 & 0 & 1 & 3 & 0 \\
\hline & Hafizabad & 0 & 0 & 0 & 16 & 0 & 0 & 0 & 0 & 0 & 1 & 0 \\
\hline & Gujrat & 0 & 0 & 0 & 19 & 2 & 7 & 2 & 0 & 3 & 0 & 0 \\
\hline & Bhakkar & 0 & 0 & 0 & 1 & 0 & 0 & 0 & 0 & 2 & 1 & 0 \\
\hline & Multan & 0 & 0 & 0 & 1 & 0 & 0 & 0 & 0 & 0 & 0 & 0 \\
\hline & Taxila & 0 & 0 & 0 & 7 & 0 & 3 & 0 & 0 & 0 & 0 & 0 \\
\hline & Sialkot & 0 & 0 & 0 & 0 & 1 & 0 & 1 & 0 & 2 & 2 & 0 \\
\hline Islamabad & Islamabad & 3 & 1 & 0 & 30 & 4 & 0 & 20 & 0 & 6 & 0 & 303 \\
\hline \multirow[t]{2}{*}{ KPK } & Swat & 4 & 0 & 0 & 0 & 2 & 0 & 4 & 0 & 0 & 1 & 8 \\
\hline & Total & 12 & 2 & 5 & 287 & 105 & 35 & 105 & 1 & 45 & 22 & 393 \\
\hline
\end{tabular}


Table 7. Number of tick species (males) found on various animals.

\begin{tabular}{ccccc}
\hline Tick Species & Goat & Sheep & Buffalo & Cattle \\
\hline Haemaphysalis punctata & 11 & 1 & 0 & 0 \\
Rhipicephalus sanguineus & 350 & 34 & 6 & 3 \\
Haemaphysalis sulcata & 0 & 0 & 2 & 0 \\
Hyalomma anatolicum & 27 & 9 & 8 & 243 \\
Hyalomma detritum & 44 & 18 & 1 & 42 \\
Hyalomma excavatum & 8 & 3 & 1 & 23 \\
Hyalomma marginatum & 21 & 13 & 0 & 71 \\
Rhipicephalus microplus & 2 & 1 & 0 & 42 \\
Rhipicephalus decoloratus & 2 & 0 & 1 & 1 \\
Hyalomma rufipes & 0 & 0 & 0 & 1 \\
Hyalomma dromedarii & 4 & 0 & 0 & 1 \\
\hline
\end{tabular}

\section{Discussion}

Tick identification was performed morphologically using dichotomous keys. One potential shortcoming of this project was the identification of only male ticks. Eleven tick species in three genera were identified. Male ticks of these species all feed on livestock and are implicated in the transmission of tick-borne diseases. In areas where resources for molecular identification of tick species are not available, researchers must rely on traditional morphological identification methods. It will be valuable to develop regionally specific identification keys that reflect all species, ages, and sexes of ticks likely to be encountered. Some areas of Punjab, Swat, and Islamabad had the highest diversity of tick species observed amongst livestock at a given site in Pakistan. The diversity of tick species observed may be due to the collection of ticks from a variety of livestock hosts. Identified species included several important disease vectors, e.g., Rhipicephalus, Hyalomma $[7,12,13,50,51]$ and Haemaphysalis [27-29].

The highest proportion of livestock infested with ticks was observed in cattle. This may be due to their thin skin and the favorable habitat and climatic conditions for ticks in Pakistan [20]. Our results regarding lower tick infestation rates in buffalo as compared to cattle are similar to the previous findings that reported a lower prevalence of tick infestation in buffalo than in cattle $[4,21,34]$.

The tick infestation rate was higher in sheep than in goats. This pattern has been observed in some studies of tick infestation of livestock in Pakistan [52,53]. Another study observed the opposite: that infestation was lower in sheep (11.1\%) as compared to goats $(60.0 \%)$ [7]. The lower rate of tick infestation in goats was maybe due to pasturing in steep and rocky habitats that limit contact with other species of livestock [54].

Exotic livestock breeds and their crosses have longer and denser hair, which makes them an easy victim of tick infestation due to extensive sheltered attachment space. The lower infestation rate in indigenous breeds (Sahiwal cattle) was also may be due to the development of resistance due to constant exposure to parasites [9,55]. Higher rates of tick infestation in exotic breeds of cattle have been noted in previous studies in Pakistan [7,12-14,55-57] as well as in Egypt [58]. Previous studies [4,24] also reported higher tick infestation rates in local breeds of cattle, which is also observed in our study, as the Dhanni breed of cattle were highly infested with ticks. Our results regarding the higher rate of tick infestation in crossbred cattle disagree with several other studies that observed a lower rate of infestation in cross breeds $[34,56,59]$

The higher rates of tick infestation observed in the summer are likely due to the combination of increased moisture and higher temperature $[48,60]$. Previous studies have shown peak infestation rates occurring in the summer $[57,61,62]$ or during other seasons $[63,64]$ depending on local climatic and environmental conditions, such as humidity, temperature, and host animal availability [65-67]. As large-bodied ticks, Hyalomma is generally more resistant to desiccation and some species, such as H. dromedarii, are well adapted to living in dry, even desert habitats [68]. 
Animal age had an important effect on the prevalence of ticks [69]. Young and adult cattle were heavily infested with ticks as compared to calves as has been previously reported $[7,24,57]$. Grooming of calves and the smaller surface area of animals may be factors in the lower tick burdens [70]. In sheep and goats, age had no significant effect on tick infestation, as others have described [53].

Female cattle, sheep, and goats were slightly more likely to have ticks than males. This result is contrary to some previous studies [56,71]. In buffalo, males were more likely to be infested than females, as has been previously described [21].

\section{Conclusions}

This study described the prevalence of tick infestation in cattle, sheep, goats, and buffalo in Punjab Province, Khyber Pakhtunkhwa Province, and Islamabad. Eleven tick species that can transmit a variety of pathogens to livestock and humans were identified. This information will help develop locally appropriate tick control and education programs in the region.

Author Contributions: S.S.K. conducted the study and wrote the manuscript; M.S.A. helped in sampling; M.R.K. and R.J.B. did revisions in the manuscript; H.A. helped in the research and supervised the study; J.D.O. helped in tick species identification and writing. All authors have read and agreed to the published version of the manuscript.

Funding: This research did not receive any funding.

Institutional Review Board Statement: The study was conducted according to the Institutional guidelines and approved by the Ethical Committee of COMSATS University (permit no. CUI/Bio/ $\mathrm{ERB} / 2021 / 42)$.

Informed Consent Statement: Not applicable.

Data Availability Statement: Specimens of female and immature ticks have been retained at the University of Minnesota Division of Environmental Health Sciences and are available for study.

Acknowledgments: The authors are thankful to Muhammad Arslan for his help in statistical analysis and the biosciences department, COMSATS University, who spent their crucial time to complete this research. Wasim Haider helped in the statistical analysis.

Conflicts of Interest: The authors declare that they have no conflict of interest.

\section{References}

1. Ministry of Finance, Government of Pakistan. Available online: http://finance.gov.pk/survey_1314.html (accessed on 2 January 2022).

2. Irshad, N.; Qayyum, M.; Hussain, M.; Khan, M.Q. Prevalence of tick infestation and theileriosis in sheep and goats. Pak. Vet. J. 2010, 30, 178-180.

3. Mather, T.N.; Abdullah, G.A. Building molecular biology capacity for preventing tick-transmitted diseases in Pakistan. Pak. USA Sci. Technol. Coop. Program 2015, 11, 15-23.

4. Ramzan, M.; Naeem-Ullah, U.; Saba, S.; Iqbal, N.; Saeed, S. Prevalence and identification of tick species (Ixodidae) on domestic animals in district Multan, Punjab Pakistan. Int. J. Acarol. 2020, 46, 83-87. [CrossRef]

5. APLDA. All Pakistan Livestock and Dairy Association. Available online: http://aplda.org.pk/statstics.html (accessed on 2 January 2022).

6. FAO. Dairy Development in Pakistan. Available online: http://www.fao.org/3/aal750e.pdf (accessed on 2 January 2022).

7. Rehman, A.; Nijhof, A.M.; Sauter-Louis, C.; Schauer, B.; Staubach, C.; Conraths, F.J. Distribution of ticks infesting ruminants and risk factors associated with high tick prevalence in livestock farms in the semi-arid and arid agro-ecological zones of Pakistan. Parasites Vectors 2017, 10, 190. [CrossRef]

8. Ali, A.; Ahelha, S.; Zahid, H.; Ullah, F.; Zeb, I.; Ahmed, H.; da Silva Vaz, I., Jr.; Tanaka, T. Molecular survey and spatial distribution of Rickettsia spp. in ticks infesting free-ranging wild animals in Pakistan (2017-2021). Pathogens 2022, 11, 162. [CrossRef]

9. Jongejan, F.; Uilenberg, G. The global importance of ticks. Parasitology 2004, 129, S3-S14. [CrossRef]

10. Sonenshine, D.E.; Roe, R.M. Biology of Ticks, 2nd ed.; Oxford University Press: New York, NY, USA, 2014; pp. 353-381.

11. Kaur, D.; Jaiswal, K.; Mishra, S. Studies on prevalence of ixodid ticks infesting cattle and their control by plant extracts. IOSR J. Pharm. Biol. Sci. Ver. III 2015, 10, 1-11. 
12. Sajid, M.S.; Iqbal, Z.; Khan, M.N.; Muhammad, G. Prevalence and associated risk factors for bovine tick infestation in two districts of lower Punjab, Pakistan. Prev. Veter. Med. 2009, 92, 386-391. [CrossRef]

13. Iqbal, A.; Sajid, M.S.; Khan, M.N.; Khan, M.K. Frequency distribution of hard ticks (Acari: Ixodidae) infesting bubaline population of district Toba Tek Singh, Punjab, Pakistan. Parasitol. Res. 2013, 112, 535-541. [CrossRef]

14. Farooqi, S.H.; Ijaz, M.; Saleem, M.H.; Rashid, M.I.; Oneeb, M.; Khan, A.; Aqib, A.I.; Mahmood, S. Distribution of ixodid tick species and associated risk factors in temporal zones of Khyber Pakhtunkhwa Province, Pakistan. Pak. J. Zool. 2017, 49, 1937-2341. [CrossRef]

15. Muhammad, A.; Bashir, R.; Mahmood, M.; Afzal, M.S.; Simsek, S.; Awan, U.A.; Khan, M.R.; Ahmed, H.; Cao, J. Epidemiology of Ectoparasites (Ticks, Lice, and Mites) in the Livestock of Pakistan: A Review. Front. Vet. Sci. 2021, 8, 780738. [CrossRef] [PubMed]

16. Mushtaq, A.; Shoukat, T.; Mumtaz, T.; Qasim, M.; Ajmal, K.; Fatima, N.; Khan, A.; Kouser, M.; Hussain, N.; Khan, S.S.; et al. Tick-borne Diseases in Sheep and Goats in Pakistan: A Systematic Review and Meta-analysis. Acta Parasitol. 2021, 66, 1316-1325. [CrossRef] [PubMed]

17. Mustafa, I.; Saman Asif, S.; Ahmed, H. Seasonal activity of tick infestation in goats and buffalo of Punjab province (District Sargodha), Pakistan. Kafkas Univ. Vet. Fak. Derg. 2014, 20, 655-662.

18. Jonsson, N. The productivity effects of cattle tick (Boophilus microplus) infestation on cattle, with particular reference to Bos indicus cattle and their crosses. Veter. Parasitol. 2006, 137, 1-10. [CrossRef] [PubMed]

19. Jabbar, A.; Abbas, T.; Sandhu, Z.-U.; Saddiqi, H.A.; Qamar, M.F.; Gasser, R.B. Tick-borne diseases of bovines in Pakistan: Major scope for future research and improved control. Parasites Vectors 2015, 8, 283. [CrossRef]

20. Karim, S.; Budachetri, K.; Mukherjee, N.; Williams, J.; Kausar, A.; Hassan, M.J.; Adamson, S.; Dowd, S.E.; Apanskevich, D.; Arijo, A.; et al. A study of ticks and tick-borne livestock pathogens in Pakistan. PLoS Negl. Trop. Dis. 2017, 11, e0005681. [CrossRef]

21. Ghafar, A.; Gasser, R.B.; Rashid, I.; Ghafoor, A.; Jabbar, A. Exploring the prevalence and diversity of bovine ticks in five agro-ecological zones of Pakistan using phenetic and genetic tools. Ticks Tick-Borne Dis. 2020, 11, 101472. [CrossRef]

22. Vieira, L.L.; Canever, M.F.; Cardozo, L.L.; Cardoso, C.P.; Herkenhoff, M.E.; Neto, A.T.; Vogel, C.I.G.; Miletti, L.C. Prevalence of Anaplasma marginale, Babesia bovis, and Babesia bigemina in cattle in the Campos de Lages region, Santa Catarina state, Brazil, estimated by multiplex-PCR. Parasite Epidemiol. Control. 2019, 6, e00114. [CrossRef]

23. Estrada-Peña, A.; Szabó, M.; Labruna, M.; Mosqueda, J.; Merino, O.; Tarragona, E.; Venzal, J.M.; De La Fuente, J. Towards an Effective, Rational and Sustainable Approach for the Control of Cattle Ticks in the Neotropics. Vaccines 2019, 8, 9. [CrossRef]

24. Zeb, J.; Shams, S.; Ayaz, S.; Din, I.U.; Khan, A.; Adil, N.; Ullah, H.; Raza, A. Epidemiology of ticks and molecular characterization of Rhipicephalus microplus in cattle population in North-Western Pakistan. Int. J. Acarol. 2020, 46, 335-343. [CrossRef]

25. Durrani, A.Z.; Shakoori, A.R. Study on ecological growth conditions of cattle Hyalomma ticks in Punjab, Pakistan. Iran. J. Parasitol. 2009, 4, 19-25.

26. Durrani, A.Z.; Younus, M.; Kamal, N.; Mehmood, N.; Shakoori, A.R. Prevalence of ovine Theileria species in District Lahore, Pakistan. Pak. J. Zool. 2011, 43, 57-60.

27. Levine, N.D. Protozoan Parasites of Domestic Animals and of Man; Nabu Press: Charleston, SC, USA, 2011.

28. Aktas, M.; Altay, K.; Dumanli, N. PCR-based detection of Theileria ovis in Rhipicephalus bursa adult ticks. Vet. Parasitol. 2006, 140, 259-263. [CrossRef] [PubMed]

29. Mans, B.J.; Pienaar, R.; Latif, A.A. A review of Theileria diagnostics and epidemiology. Int. J. Parasitol. Parasites Wildl. 2015, 4, 104-118. [CrossRef] [PubMed]

30. Bente, D.A.; Forrester, N.L.; Watts, D.M.; McAuley, A.J.; Whitehouse, C.A.; Bray, M. Crimean-Congo hemorrhagic fever: History, epidemiology, pathogenesis, clinical syndrome and genetic diversity. Antivir. Res. 2013, 100, 159-189. [CrossRef]

31. Otranto, D.; Dantas-Torres, F.; Giannelli, A.; Latrofa, M.S.; Cascio, A.; Cazzin, S.; Ravagnan, S.; Montarsi, F.; Zanzani, S.A.; Manfredi, M.T.; et al. Ticks infesting humans in Italy and associated pathogens. Parasites Vectors 2014, 7, 328. [CrossRef]

32. WHO. Surveillance, Forecasting and Response: Crimean-Congo Haemorrhagic Fever in Pakistan; World Health Organization: Geneva, Switzerland, 2014.

33. Khan, A.; Nasreen, N.; Niaz, S.; Shah, S.A.S.; Mitchell, R.D., III; Ayaz, S.; Naeem, H.; Khan, L.; De León, A.P. Tick burden and tick species prevalence in small ruminants of different agencies of the Federally Administered Tribal Areas (FATA), Pakistan. Int. J. Acarol. 2019, 45, 374-380. [CrossRef]

34. Ahmad, Z.; Anwar, Z.; Adnan, M.; Imtiaz, N.; Rashid, H.U.; Gohar, F. Collection and prevalence of ticks in cattles and buffaloes from free-range management systems of Islamabad. J. Basic Appl. Zool. 2019, 80, 12. [CrossRef]

35. Lihou, K.; Vineer, H.R.; Wall, R. Distribution and prevalence of ticks and tick-borne disease on sheep and cattle farms in Great Britain. Parasites Vectors 2020, 13, 406. [CrossRef]

36. Kasi, K.K.; von Arnim, F.; Schulz, A.; Rehman, A.; Chudhary, A.; Oneeb, M.; Sas, M.A.; Jamil, T.; Maksimov, P.; Sauter-Louis, C.; et al. Crimean-Congo haemorrhagic fever virus in ticks collected from livestock in Balochistan, Pakistan. Transbound. Emerg. Dis. 2020, 67, 1543-1552. [CrossRef]

37. Available online: https:/ / punjab.gov.pk/about_punjab_geography\#: \{\}:text=Punjab\%20is\%20the \%20most $\% 20$ populous, the \% 20national $\% 20$ figure $\% 20$ of $\% 20164$ (accessed on 3 January 2022).

38. Khan, D.; Saeed, A.; Junaid, A.; Qamar, I.; Yazdan, F.; Din, S.; Tariq, M. Assessment of riparian vegetation in Dhrabi watershed and Chakwal Region in Pakistan. Pak. J. Agric. Res. 2016, 29, 260-267. 
39. Available online: http:/ / kpboit.gov.pk/swat-district/\#: \{\}:text=Livestock\%20and\%20dairy\%20development $\% 20$ sector,80048\%20 Sheep \%20and\%20236\%2C229\%20Goats (accessed on 2 January 2022).

40. Available online: https://www.visitswatvalley.com/swat-weather/\#: \{\}:text=The \%20swat $\% 20 w e a t h e r \% 20 v a r i e s \% 20 b y, u p p e r \%$ 20regions\%20i.e.\%20in\%20Kalam (accessed on 2 January 2022).

41. Available online: https://www.britannica.com/place/Pakistan/Economy (accessed on 2 January 2022).

42. Lorenz, R.T. Disease surveillance in livestock-A guide for the determination of sample sizes. Bonn AID 1990, 1-51.

43. Ica, A.; Inci, A.; Vatansever, Z.; Karaer, Z. Status of tick infestation of cattle in the Kayseri region of Turkey. Parasitol. Res. 2007, 101, 167-169. [CrossRef]

44. Soulsby, E. Helminths, arthropods and protozoa of domesticated animals. Protozoology 1982, $291,56-67$.

45. Kaiser, M.N.; Hoogstraal, H. The Hyalomma ticks (Ixodoidea, Ixodidae) of Afghanistan. J. Parasitol. 1963, 49, 130-139. [CrossRef] [PubMed]

46. Walker, A.R. Ticks of Domestic Animals in Africa: A Guide to Identification of Species; Bioscience Reports: Edinburgh, UK, 2003; pp. 3-210.

47. Hosseini-Chegeni, A.; Tavakoli, M.; Telmadarraiy, Z. The updated list of ticks (Acari: Ixodidae \& Argasidae) occurring in Iran with a key to the identification of species. Syst. Appl. Acarol. 2015, 24, 2133-2166.

48. Tylor, M.O.; Coop, R.L.; Wall, R.L. Veterinary Parasitology, 3rd ed.; Blackwell Publishing Oxford: Ames, IA, USA, 2007 ; pp. 838-839.

49. Walpole, R.E.; Myers, R.H.; Myers, S.L.; Ye, K. Probability and Statistics for Engineers and Scientists; Macmillan: New York, NY, USA, 1993; Volume 5.

50. Telmadarraiy, Z.; Chinikar, S.; Vatandoost, H.; Faghihi, F.; Hosseini-Chegeni, A. Vectors of Crimean Congo hemorrhagic fever virus in Iran. J. Arthropod-Borne Dis. 2015, 9, 137.

51. Perveen, F. Distribution and identification of ixodid tick species on livestock in northern Pakistan. J. Agric. Sci. Technol. 2011, 1, 73-81.

52. Ramzan, M.; Naeem-Ullah, U.; Abbas, H.; Adnan, M.; Rasheed, Z.; Khan, S. Diversity of hard ticks in goats and sheep in Multan, Punjab, Pakistan. Int. J. Agric. Biol. Res. 2019, 35, 7-9.

53. Rashid, M.; Godara, R.; Yadav, A.; Katoch, R. Prevalence of ticks in sheep and goats of Jammu region. Ind. J. Small Rum. 2018, 24, 183-186. [CrossRef]

54. Alessandra, T.; Santo, C. Tick-borne diseases in sheep and goats: Clinical and diagnostic aspects. Small Rumin. Res. 2012, 106, S6-S11. [CrossRef]

55. Ahmed, S.; Numan, M.; Manzoor, A.W.; Ali, F.A. Investigations into Ixodidae ticks in cattle in Lahore, Pakistan. Vet. Ital. 2012, 48, 185-191. [PubMed]

56. Shoaib, M.; Rashid, I.; Akbar, H.; Sheikh, A.A.; Farooqi, S.H.; Asif, M.; Khan, M.A.; Mahmood, S.; Khan, F.A. Prevalence of Rhipicephalus and Hyalomma ticks in cattle and associated risk factors in three districts of Khyber Pakhtunkhwa, Pakistan. Pak. J. Zool. 2021, 53, 777. [CrossRef]

57. Gul, S.; Ahmed, S.; Usman, T.; Khan, K.; Ayaz, S.; Gul, S.; Ali, N. Prevalence of Anaplasma marginale in tropical area of Khyber Pakhtunkhwa, Pakistan. Pak. J. Zool. 2021, 53, 1977-1980. [CrossRef]

58. Asmaa, N.M.; ElBably, M.A.; Shokier, K.A. Studies on prevalence, risk indicators and control options for tick infestation in ruminants. Beni-Suef Univ. J. Basic Appl. Sci. 2014, 3, 68-73. [CrossRef]

59. Kakar, M.E.; Khan, M.A.; Khan, M.S.; Ashraf, K.; Kakar, M.A.; Jan, S.; Razzaq, A. Prevalence of tick infestation in different breeds of cattle in Balochistan. J. Anim. Plant Sci. 2017, 27, 797-802.

60. Aktas, M.; Dumanli, N.; Angin, M. Cattle infestation by Hyalomma ticks and prevalence of Theileria in Hyalomma species in the east of Turkey. Veter. Parasitol. 2004, 119, 1-8. [CrossRef]

61. Rony, S.A.; Mondal, M.M.H.; Begum, N.; Islam, M.A.; Affroze, S. Epidemiology of ectoparasitic infestations in cattle at Bhawal forest area, Gazipur. Bangladesh J. Vet. Med. 2010, 8, 27-33. [CrossRef]

62. Ullah, N.; Durrani, A.Z.; Avais, M.; Ahmad, N.; Ullah, S.; Ullah, S.; Khan, M.A.; Haq, I.U.; Khan, N.U. A first report on prevalence of caprine theileriosis and its association with host biomarkers in Southern Khyber Pakhtunkhwa, Pakistan. Small Rumin. Res. 2018, 159, 56-61. [CrossRef]

63. Shah, S.S.A.; Khan, M.I.; Rahman, H.U. Epidemiological and hematological investigations of tick-borne diseases in small ruminants in Peshawar and Khyber Agency, Pakistan. J. Adv. Parasitol. 2017, 4, 15-22.

64. Naz, S.; Maqbool, A.; Ahmed, S.; Ashraf, K.; Ahmed, N.; Saeed, K.; Latif, M.; Iqbal, J.; Ali, Z.; Shafi, K.; et al. Prevalence of theileriosis in small ruminants in Lahore-Pakistan. J. Vet. Anim. Sci. 2012, 2, 16-20.

65. Díaz MÁ, A.; Silva, B.J.L.; de Magalhães Labarthe, A.C.L.; Vivas, R.I.R. Infestación natural de hembras de Boophilus microplus Canestrini, 1887 (Acari: Ixodidae) en dos genotipos de bovinos en el trópico húmedo de Veracruz, México. Vet. México 2007, 38, 503-509.

66. Magona, J.W.; Walubengo, J.; Olaho-Mukani, W.; Jonsson, N.N.; Welburn, S.W.; Eisler, M.C. Spatial variation of tick abundance and seroconversion rates of indigenous cattle to Anaplasma marginale, Babesia bigemina and Theileria parva infections in Uganda. Exp. Appl. Acarol. 2011, 55, 203-213. [CrossRef] [PubMed]

67. Greenfield, B.P.J. Environmental parameters affecting tick (Ixodes ricinus) distribution during the summer season in Richmond Park, London. Biosci. Horiz. 2011, 4, 140-148. [CrossRef] 
68. Fard, S.R.N.; Fathi, S.; Asl, E.N.; Nazhad, H.A.; Kazeroni, S.S. Hard ticks on one-humped camel (Camelus dromedarius) and their seasonal population dynamics in southeast, Iran. Trop. Anim. Health Prod. 2012, 44, 197-200. [CrossRef]

69. Manan, A.; Khan, B.A.Z. Prevalence and identification of ixodid tick genera in frontier region Peshawar. J. Agric. Biol. Sci. 2007, 2, 21-25.

70. Mooring, M.S.; Benjamin, J.E.; Harte, C.R.; Herzog, N.B. Testing the interspecific body size principle in ungulates: The smaller they come, the harder they groom. Anim. Behav. 2000, 60, 35-45. [CrossRef]

71. Musa, H.I.; Jajere, S.M.; Adamu, N.B.; Atsanda, N.N.; Lawal, J.R.; Adamu, S.G.; Lawal, E.K. Prevalence of tick infestation in different breeds of cattle in Maiduguri, Northeastern Nigeria. Bangladesh J. Vet. Med. 2014, 12, 161-166. [CrossRef] 